\author{
Aneta Boldyrew \\ Pracownia Historii Oświaty \\ Wydziat Nauk o Wychowaniu \\ Uniwersytet Łódzki
}

\title{
Społeczno-obyczajowe uwarunkowania porzucania dzieci i dzieciobójstwa w Królestwie Polskim na przelomie XIX i XX wieku*
}

\begin{abstract}
Aneta Bołdyrew, Social and Moral Conditions for Abandonment of Children and Infanticide in the Kingdom of Poland at the Turn of the 20th Century*.

In the last decades of the 19th century, in the Kingdom of Poland, the scale of social pathologies increased, including infanticide and abandonment of children. Such phenomena were conditioned by a number of social, demographic, economic and moral factors; the processes of urbanization and industrialization played a major part as they resulted in the inflow of great masses of people to cities, who experienced difficulties in the adaptation to new conditions. Poverty, illiteracy, often the lack of steady employment, disintegration of the traditional social groups and the system of values lead to the destabilization of the situation of the immigratory population. This made starting a family difficult, leading to a large number of informal relationships, lone mothers and illegitimate children deprecated by public opinion. The hardships of lonely maternity, lack of support on the part of the state administration and shelters determined the increased number of crimes against children. Also, unfavourable was a common practice of employing wet nurses, who left their own children in the care of hired babysitters, who were knowingly called the "producers of angels" because of the fact of a huge mortality rate among such infants, dying as a result of disastrous care, or, sometimes, simply murdered. Social work of pedagogues, doctors and lawyers slightly improved the fate of the poorest mothers, who most often committed infanticide and abandonment of their children, and, consequently, the scale of such phenomena at the beginning of the 20th century slightly decreased.
\end{abstract}

Keywords: abandoned children, infanticide, Kingdom of Poland at the turn of the 20th century

Industrializacja i urbanizacja były dwoma najbardziej charakterystycznymi procesami dziewiętnastowiecznej Europy. Sprzyjały rozwojowi gospodarczemu i cywilizacyjnemu, ale jednocześnie determinowały przemiany społeczne i obyczajowe, które wbrew deklarowanemu merytokratycznemu ${ }^{1}$ ideałowi społeczeństwa obok wielu pozytywnych konse-

\footnotetext{
* Problematyka ta była podejmowana w artykule: A. Bołdyrew, Dzieciobójstwo i porzucenia dzieci w Królestwie Polskim jako przejaw patologii życia społecznego. Zarys problemu w świetle publicystyki przełomu XIX
} 
kwencji niosły ze sobą polaryzację społeczeństwa, eskalację ubóstwa i nierówności, wzrost patologii społecznych. Wbrew nadziejom entuzjastów cywilizacji przemysłowej rozpad stanowej struktury nie oznaczał zmniejszenia rozwarstwienia społecznego. W całej Europie przemianom społeczno-gospodarczym towarzyszył wzrost przestępczości i patologii społecznych: alkoholizmu, prostytucji, dzieciobójstwa, żebractwa, bezdomności. Podobne procesy zachodziły także na ziemiach polskich, ze szczególnym natężeniem na obszarze Królestwa Polskiego, przeżywającego gwałtowne przeobrażenia, determinowane w ostatnim trzydziestoleciu XIX w. i na początku XX w. dynamicznym wzrostem uprzemysłowienia i demograficznym rozwojem miast. Procesom tym towarzyszyły również nasilające się patologie społeczne, co szybko stało się wymownym dowodem, że mimo założenia o progresywnej modernizacji, trudno rozpatrywać zachodzące zmiany społeczno- -ekonomiczne tylko w kategoriach postępu. W wielkich miastach tworzyły się dzielnice, zamieszkiwane przez najuboższe grupy ludności. Obszary te uznawane były za siedliska biedy i występku. Owe ,złe dzielnice” przyczyniały się do traktowania problemu patologii społecznych jako zjawiska charakterystycznego przede wszystkim dla kultury mieszczańskiej, będącej wytworem cywilizacji przemysłowej².

Patologie społeczne, szczególnie nasilone i widoczne w wielkomiejskiej przestrzeni budziły niechęć, odrazę, potępienie, zgorszenie dużej części opinii publicznej; opis szczególnie drastycznych przejawów trafiał na łamy prasy, wywołując tanią sensację. Jednocześnie w omawianym okresie wzrastała liczba inteligencji - grupy społecznej, próbującej w publicznej dyskusji określić przyczyny patologii i wskazywać rozwiązania

i XX w., „Studia z Historii Społeczno-Gospodarczej XIX i XX wieku” t. 5, 2008, s. 278-299, gdzie dokonano próby analizy zagadnienia z uwzględnieniem m.in. aspektów prawno-historycznych. Celem tekstu było przedstawienie problemu w świetle publicystyki (artykuł miał charakter głównie sprawozdawczy). Niniejsze opracowanie odwołuje się do poczynionych wcześniej ustaleń. Jego zasadniczym celem, w zamierzeniu autorki, jest próba wskazania przyczyn i społeczno-kulturowych uwarunkowań zjawiska dzieciobójstwa i porzucania dzieci (w oparciu o wiedzę źródłową i pozaźródłową), także z wykorzystaniem metod i pojęć stosowanych w socjologii. Przedstawiono wyniki dalszej kwerendy źródłowej, obejmującej czasopiśmiennictwo społeczno-kulturalne, społeczno-polityczne, prawnicze, lekarskie, dążąc do możliwie wielostronnego omówienia problemu.

1 Propagowanie merytokratycznego wzorca w życiu społecznym rozpoczęło się już na przełomie XVIII i XIX w., kiedy jak zaznacza B. Szacka, niektórzy ideologowie ,[...] nie oczekiwali zniesienia nierówności, ale żywili przekonanie, że likwidacja zamkniętych stanów tworzących hierarchie da początek takiemu społeczeństwu, w którym miejsce człowieka w układzie nierówności zależne będzie jedynie od jego zdolności oraz pracowitości. [...] Tak więc już u zarania nowoczesnych społeczeństw przemysłowych powstał wzorzec społeczeństwa merytokratycznego, to jest takiego, w którym miejsce człowieka w hierarchii społecznej zależy od niego samego [...]". B. Szacka, Wprowadzenie do socjologii, Warszawa 2008, s. 284. Wzrost takich tendencji, nadal pozostających w sferze teoretycznego modelu, widać w ostatnich dekadach XIX w.

2 Okres pozytywizmu przyniósł fascynację miastem, w programach społecznych podkreślano, że postęp cywilizacyjny dokona się dzięki kulturze mieszczańskiej; podobny punkt widzenia przyjęło wielu polskich ideologów tego okresu. Jednak już w latach 70.-80. XIX w. zaczęto zwracać uwagę na niekorzystne aspekty życia w mieście przemysłowym. W latach 90. coraz bardziej podkreślano negatywny wpływ życia miejskiego na relacje społeczne, funkcjonowanie rodziny, poziom kultury. Realiom miejskiego życia przypisywano odpowiedzialność za wzrost przestępczości i patologii społecznych. (E. Ihnatowicz, Miasto kryminalne?, w: Miasto - kultura - literatura. Wiek XIX, red. J. Data, Gdańsk 1993, s. 122; J. Jedlicki, Świat zwyrodniały. Lęki i wyroki krytyków nowoczesności, Warszawa 2000, passim. Por. E. Kaczyńska, Złe dzielnice: marginalizacja a ruchliwość społeczna. Rozwój miast w XIX i XX wieku, w: Wspólnoty lokalne i środowiskowe w miastach i miasteczkach ziem polskich pod zaborami i po odzyskaniu niepodległości, red. M. Nietyksza, Toruń 1998, s. 267-296). 
problemu czy choćby zmniejszenie jego rozmiarów ${ }^{3}$. Do najbardziej empatycznych społecznie grup inteligencji zawodowej należeli lekarze, prawnicy, pedagodzy, publicyści. Wrażliwość na problemy społeczne była ważnym elementem inteligenckiego etosu, zwłaszcza w okresie fin de siecle’u, czynnikiem różniącym inteligencję od filisterskiego mieszczaństwa. Jednymi z najbardziej poruszających opinię publiczną Królestwa patologii społecznych było dzieciobójstwo, rozumiane jako zabicie dziecka w czasie porodu albo niedługo po nim oraz porzucanie dzieci. Nagłaśniane przez prasę wypadki szokowały i zmuszały do poszukiwania przyczyn nasilania się od lat 70. tej szczególnie drastycznej patologii.

Rozpatrując problem uwarunkowań dzieciobójstwa i porzucania dzieci u schyłku XIX i na początku XX w., trzeba przypomnieć, że towarzyszyły one społeczeństwom od wieków ${ }^{4}$. Skalę zjawiska w średniowieczu i dobie nowożytnej trudno określić, księgi sądowe przekazują informacje na temat osądzonych spraw; z pewnością znaczna liczba przypadków dzieciobójstwa (w okresie staropolskim wliczano w to także celowe wywołanie poronienia) pozostała niewykryta ${ }^{5}$. W Królestwie Polskim już w okresie przed powstaniem listopadowym kobiety często były oskarżane o zaniedbanie opieki nad dziećmi, porzucanie noworodków, a także o dzieciobójstwo i pozbycie się płodu. Jak podaje M. Karpińska, w 1830 r. w Królestwie Polskim co siódma kobieta przebywająca w aresz-

\footnotetext{
${ }^{3} \mathrm{Na}$ temat form działalności i postaw inteligencji wobec patologii społecznych zob.: A. Bołdyrew, Inteligencja polska wobec problemu patologii społecznych w przestrzeni wielkiego miasta $w$ Królestwie Polskim na przełomie XIX $i$ XX w., „Studia Humanistyczne Wydziału Farmaceutycznego Akademii Medycznej we Wrocławiu", t. 2: Człowiek, natura, kultura - studia z historii, antropologii medycyny i farmacji społecznej, 2009, s. 345-369. O znaczeniu pracy społecznej, w tym działań na rzecz podniesienia poziomu cywilizacyjnego niższych grup ludności, krzewienia oświaty, walki z ubóstwem i patologiami dla etosu i autostereotypu inteligencji pisało w ostatnim czasie wielu historyków, analizujących problemy funkcjonowania, działalności i znaczenia inteligencji na ziemiach polskich w XIX i na początku XX w. Zob. m.in.: M. Janowski, Narodziny inteligencji 1750-1831, Warszawa 2008; J. Jedlicki, Błedne koło 1832-1864, Warszawa 2008; M. Micińska, Inteligencja na rozdrożach 1864-1918, Warszawa 2008; M. Iwańska, W poszukiwaniu inteligenckiej tożsamości w XIX wieku. Przykład tódzki, w: Historia-mentalność-tożsamość. Studia z historii, historii historiografii i metodologii historii, red. K. Polasik-Wrzosek, W. Wrzosek, L. Zaszkilniak, Poznań 2010, s. 261-271; T. Pudłocki, Iskra światła czy kopcaca pochodnia? Inteligencja w Przemyślu 1867-1939, Kraków 2009. Bogata literatura przedmiotu, zamieszczona w tych pozycjach, odwołuje do klasycznych opracowań wybitnych historyków, w tym R. Czepulis-Rastenis, L. Hassa, W. Molika, I. Homoli-Skąpskiej, J. Żarnowskiego.

${ }^{4}$ Dzieciobójstwo zaliczyć należy do tych zjawisk życia społecznego, z jakimi borykały się społeczeństwa od zarania cywilizacji. Nie zawsze było uważane za patologię; w państwach starożytnych aprobowano uśmiercanie dzieci, zwłaszcza chorych i kalekich. Dzieciobójstwa dokonywano również w przypadku nadmiernego powiększenia rodziny, uznając eliminację niepożądanego dziecka za prostą metodę ograniczenia przyrostu naturalnego. Zasadniczy przełom przyniósł początek średniowiecza, w doktrynie chrześcijańskiej bowiem zabicie dziecka uchodziło za szczególnie ciężką zbrodnię. Kodeksy karne ówczesnej Europy wprowadziły surowe kary dla matek dopuszczających się dzieciobójstwa (kara śmierci - dokonywana w szczególnie okrutny i hańbiący sposób - przez zakopanie żywcem, wbicie na pal, utopienie w worku; w 1532 r. w Constitutio Criminalis Carolinae, czyli kodeksie karnym cesarza Karola V nakazywano poddanie kobiety przed śmiercią torturom). Okrutne kary miały odstraszyć kobiety przed popełnianiem dzieciobójstwa, ale nawet najbardziej drastyczne metody nie eliminowały tej patologii. J. A. Bartoszewski, J. Halaunbrenner-Lisowska, Dzieciobójstwo aspekty prawne, medyczne i społeczne, Warszawa 1974, s. 6-7; K. Marzec-Holka, Dzieciobójstwo przestępstwo uprzywilejowane czy zbrodnia, Bydgoszcz 2004, s. 11-13.

5 Zob. szerzej M. Delimata, Dziecko w Polsce średniowiecznej, Poznań 2004, s. 188-194; D. Żołądź-Strzelczyk, Dziecko w dawnej Polsce, Poznań 2002, s. 277-282.
} 
cie dopuściła się dzieciobójstwa ${ }^{6}$. Nasilenie dzieciobójstwa i porzucania dzieci nastąpiło w okresie po powstaniu styczniowym, co było uwarunkowane szeregiem czynników społecznych, demograficznych, ekonomicznych, obyczajowych. Celem niniejszego artykułu jest określenie najważniejszych przyczyn, które spowodowały eskalację tego zjawiska w Królestwie Polskim w ostatnich dekadach XIX w.

Przede wszystkim należy zwrócić uwagę, że tempo rozwoju miast Królestwa Polskiego po 1865 r. w wielu wypadkach przyczyniało się do gwałtownego przyrostu ich ludności, co powodowało trudności w integracji miejskiej społeczności. Ośrodki wielkomiejskie, dzięki uprzemysłowieniu przeżywające bujny rozwój, stwarzały na nieznaną dotąd skalę szanse poprawy warunków bytu, społecznego awansu, ale także degradacji ${ }^{7}$. Przestrzeń miejska intensyfikowała, z racji zagęszczonego skupienia ludności o skrajnie różnych zasobach materialnych i stylach życia, antagonizmy i rozwarstwienie społeczeństwa. Warunki życia w wielkim mieście wpływały na dezintegrację tradycyjnego systemu wartości ludności napływowej, zagubionej w anonimowej wielkomiejskiej cywilizacji, bezradnej w obliczu problemów dnia codziennego ${ }^{8}$. Jak pisał Aleksander Kamiński, ,industrializacja i urbanizacja sprzyjały rozwojowi gospodarczemu, ale zarazem i proletaryzacji mas ludzkich oraz rozkładowi tradycyjnych grup społecznych (rodziny, społeczności lokalnych, sąsiedztwa)" ". Dla wielu osób napływających ze wsi problemem w stabilizacji pozycji w wielkomiejskiej przestrzeni były niskie kwalifikacje zawodowe, brak pracy, a w konsekwencji brak środków finansowych pozwalających na godną egzystencję. Prowadziło to do głębokiego zróżnicowania społeczności i powstawania grupy usytuowanej na najniższym szczeblu w miejskiej hierarchii, marginalizowanej przez pozostałą ludność. Materialne ubóstwo, połączone z wykluczeniem z pełnego uczestnictwa w życiu społecznym, analfabetyzmem i brakiem wykształcenia prowadziło do przyjmowania postaw społecznie nie akceptowanych, negatywnych, często prowadzących do konfliktu z prawem. W przypadku kobiet do najczęstszych patologii należało prostytuowanie się, dzieciobójstwo i porzucanie dzieci.

W warunkach dynamicznego rozwoju demograficznego w ramach imigracji pouwłaszczeniowej w miastach Królestwa nastąpiło gruntowne przeobrażenie ich społeczności, zarówno w zakresie zmian ilościowych, jak i jakościowych, o charakterze kulturowym. Proces intensywnego napływu ludności był szczególnie widoczny w największych ośrodkach miejskich - w Warszawie (liczącej w 1872 r. 276 tys. ludności, w 1897 r. 600 tys., w 1913 r. ok. 1 mln) i Łodzi (liczącej w 1872 r. ok. 50 tys. ludności, w 1897 r. 337 tys., w 1913 r. ok. 600 tys.) ${ }^{10}$. Gwałtowny wzrost demograficzny cechował się wy-

\footnotetext{
${ }^{6}$ M. Karpińska, Złodzieje, agenci, policyjni strażnicy... Przestępstwa pospolite $w$ Warszawie 1815-1830, Warszawa 1999, s. 98-99.

${ }^{7}$ A. Żarnowska, Wspólnoty lokalne i środowiskowe $w$ miastach i miasteczkach ziem polskich pod zaborami i po odzyskaniu niepodlegtości: tradycyjne czy nowoczesne? w: Wspólnoty lokalne..., s. 17.

${ }^{8}$ W. Puś, Miasto przemystowe $w$ XIX $i$ XX wieku. Jego funkcje społeczne, w: Wielkie miasto. Czynniki integrujące i dezintegrujące, red. D. Bieńkowska, Łódź 1995, s. 58-64.

${ }^{9}$ Cyt. za: S. Kawula, Debata o pedagogice społecznej, „Pedagogika Społeczna” 2010, nr 1, s. 20.

${ }_{10}$ M. Nietyksza, Rozwój miast $i$ aglomeracji miejsko-przemysłowych w Królestwie Polskim 1865-1914, PWN, Warszawa 1986, s. 368-369.
} 
sokim udziałem ludności napływowej. W latach 80. i 90. XIX w. ponad 47\% mieszkańców Warszawy stanowili imigranci ${ }^{11}$. W Łodzi pod koniec XIX w. 62\% jej mieszkańców urodziło się poza miastem. Jednocześnie charakterystyczną cechą struktury ludności dwóch największych miast Królestwa była liczebna przewaga kobiet. I tak w Łodzi w 1897 r. na 100 mężczyzn w wieku 15-19 lat przypadały 123 kobiety, w grupie wiekowej 20-24 współczynnik feminizacji wynosił $112^{12}$. W Warszawie przeciętnie na 100 mężczyzn przypadało 111 kobiet $^{13}$. Taka przewaga liczby kobiet w wieku matrymonialnym w stosunku do liczby mężczyzn zmniejszała szansę zamążpójścia, nie ułatwiała młodym kobietom ustabilizowania swej sytuacji rodzinnej ${ }^{14}$. Był to jeden z powodów niewielkiej spoistości rodzinnej najniższych grup miejskiego społeczeństwa; wielu ich przedstawicieli stale lub przejściowo żyło na zasadach konkubinatu. Naturalnie priorytetowe znaczenie w tej kwestii miały czynniki natury obyczajowej, niemniej struktura demograficzna wzmacniała tendencje tworzenia związków pozamałżeńskich. Rozluźnienie tradycyjnych więzi oznaczało zanik patriarchalnej kontroli rodziny. W przestrzeni wielkiego miastach, w najuboższych środowiskach przestawały obowiązywać zasady i normy, będące podstawą kodeksu wiejskich społeczności. Pozbawione wsparcia rodziny, nie posiadające jakiegokolwiek lokum, często pozostające bez środków do życia młode dziewczęta, zagubione w nowym środowisku nierzadko pochopnie nawiązywały znajomości z mężczyznami, decydowały się na pozostawanie w nieformalnym związku, część utrzymywała przypadkowe kontakty seksualne, wreszcie pewna grupa kobiet utrzymywała się z prostytucji. Wpływało to naturalnie na systematyczne zwiększanie liczby dzieci nieślubnych ${ }^{15}$. Dramat rozpoczynał się w sytuacji, kiedy kobieta zachodziła w ciążę i nie miała żadnego wsparcia ze strony ojca dziecka (który nierzadko w takiej sytuacji zrywał znajomość), a ubóstwo i brak mieszkania uniemożliwiały opiekę nad niemowlęciem.

W ostatnim trzydziestoleciu XIX w. i na początku kolejnego stulecia publicyści wiele uwagi poświęcali gwałtownemu wzrostowi liczby urodzeń „nieprawych” i jego społecznym implikacjom. Przeciwnicy zachodzących przemian cywilizacyjnych ironizowali, że unowocześnianie społeczeństwa wyraża się głównie przez zwiększenie liczby nieformalnych związków i „nieprawych” urodzeń ${ }^{16}$. Zbierający u schyłku XIX w. materiały

\footnotetext{
${ }^{11}$ M. Nietyksza, Ludność, w: I. Pietrzak-Pawłowska (red.), Wielkomiejski rozwój Warszawy do 1918 r., Książka i Wiedza, Warszawa 1973, s. 72.

12 J. K. Janczak, Ludność, w: R. Rosin, B. Baranowski, J. Fijałek (red.), Lódź. Dzieje miasta, t. I: do 1918 r., PWN, Warszawa-Łódź 1988, s. 205-206; J. K. Janczak, Demograficzne konsekwencje industrializacji okręgu łódzkiego, w: Pamiętnik XIV Powszechnego Zjazdu Historyków Polskich, Łódź, 7-10 września 1989 roku, red. S. Meller, s. 230-231.

${ }_{13}$ M. Nietyksza, Rozwój miast..., s. 297.

14 Trzeba także pamiętać, że część przybyłych ze wsi młodych kobiet traktowało pobyt i pracę w mieście jako okres przejściowy, umożliwiający zgromadzenie środków materialnych na wiano.

15 R. Buczyński, Zarysy stanu moralnego naszego społeczeństwa, t. I, Warszawa 1885, s. 124-125; T. Łepkowski, Polska - narodziny nowoczesnego narodu 1764-1870, Warszawa 1967, s. 465-466. Zob. także A. Stawarz, Obyczaj robotniczy połowy XIX wieku w świetle akt stanu cywilnego (na przykładzie Żyrardowa), „Etnografia Polska" t. XXVI, 1982, z. 2, s. 225.

${ }^{16}$ Por. Statystyka postępu, „Prawda” 1886, s. 127.
} 
z zakresu statystyki kryminalnej Roman Buczyński, który w kategoriach aksjomatu traktował nieuchronność demoralizacji społeczności wielkich miast, ubolewał nad wzrostem liczby nieformalnych związków i losem „,nędznej generacji”, będącej jej efektem ${ }^{17}$. Ale liczba dzieci nieślubnych urodzonych w Warszawie, przez wielu oceniana w kasandrycznym tonie, nie wyróżniała się na tle statystyk innych dużych miast europejskich. W Warszawie stanowiły one 31\% ogółu noworodków, podczas gdy w Moskwie 38\%, w Wiedniu 50\%, w Monachium 51\% ${ }^{18}$. Według Edwarda Prądzyńskiego w Warszawie w $1871 \mathrm{r}$. dzieci nieślubne stanowiły 26,9\%, a rok później już 30,84\%. W 1867 r. w Europie przeciętnie liczbę nieprawych dzieci szacowano na 7\% ogólnej liczby noworodków, w następnych latach odsetek ten systematycznie wzrastał. Podobna tendencja występowała w Królestwie Polskim ${ }^{19}$. Na liczbę urodzeń nieślubnych wpływał także charakter miasta. Wysoki odsetek takich urodzeń dotyczył Warszawy, a także innych wielkich ośrodków miejskich, do których napływała najliczniejsza rzesza imigrantów i gdzie następował najszybszy przyrost ludności. Liczba ta była także wyższa niż przeciętnie w miastach, w których znajdowały się garnizony wojskowe, co wiązało się z dużą liczbą prostytutek $^{20}$. Wreszcie na liczbę urodzeń nieślubnych w wielkich miastach wpływał fakt, że w wielu wypadkach kobiety z prowincji przyjeżdżały na czas ostatniego trymestru ciąży i porodu, by zataić przed otoczeniem urodzenie nieślubnego dziecka.

Skala nieślubnych narodzin miała dla problemu dzieciobójstwa i porzucania dzieci zasadnicze znaczenie. Statystyki pokazywały bowiem związki między tymi procesami. Niezamężne matki znacznie częściej decydowały się na porzucenie dziecka niż kobiety o ustabilizowanej sytuacji rodzinnej. W przeważającej większości powody porzuceń miały charakter ekonomiczny. Dla obserwatorów realiów życia codziennego w Królestwie przyczyny dzieciobójstwa i porzucania dzieci nie pozostawiały wątpliwości. Publicyści przyznawali, że w niektórych przypadkach przestępstwa dokonywane na dzieciach były wynikiem zdeprawowania kobiet z marginesu społecznego. Zdecydowanie częściej był to jednak przejaw desperacji kobiet, pozbawionych środków do życia. Trudno precyzyjnie przedstawić status społeczny i zawodowy matek decydujących się na porzucenie dzieci. Według Aleksandra Moldenhawera i Bolesława Prusa taki los spotykał dzieci

\footnotetext{
${ }^{17}$ R. Buczyński, op. cit., t. I, s. 124-127. Cenne są zebrane przez R. Buczyńskiego, od 1862 r. nauczyciela gimnazjum w Kielcach, a od 1873 r. pracownika Komisji Sprawiedliwości, dane statystyczne dotyczące patologii życia społecznego, w tym m.in. dzieciobójstwa i porzuceń. Mimo zastrzeżeń historyków co do wiarygodności liczb podawanych przez Buczyńskiego, warto korzystać z jego zestawień, konfrontując je z danymi podawanymi przez innych autorów, a przede wszystkim statystykami sądowymi. Dane liczbowe na temat dzieciobójstwa i porzuceń dzieci, liczby skazanych za przestępstwa wobec dzieci, komentarze autora zob. op. cit., t. I, s. 140-142, 154-155, 157-159, 167, dodatek I, s. 14, 27-28, 30-31, 38, 41-42; t. II, Warszawa 1886, s. 46, 117, 119, dodatek I, s. 12, 16-19, 38-39. Problem liczby związków pozamałżeńskich zob. ibidem, t. II, s. 37-39. Zob. także tego autora Stan moralny społeczeństwa naszego na podstawie wykazów statystycznych karnych, „Biblioteka Warszawska” 1874, s. 266-267, 281, 283, 286, 289-290.

18 B. Prus, Kroniki, t. III, opr. Z. Szweykowski, red. J. Baculewicz, Warszawa 1954, s. 430.

19 E. Prądzyński, O prawach kobiety, Warszawa 1875, s. 161-162. Statystyki ludności zawsze obejmowały dane dotyczące liczby dzieci nieślubnych w ogólnej liczbie narodzonych. Publikowano je np. na łamach periodyku „Ekonomista”.

${ }^{20}$ Por. J. Sikorska-Kulesza, Zło tolerowane. Prostytucja w Królestwie Polskim w XIX wieku, cop. 2004, s. $223-224$.
} 
służących, niezamężnych robotnic, prostytutek, kobiet wynajmujących się do karmienia obcych dzieci, przedstawicielek marginesu społecznego.

Statystyki kryminalne pokazywały, że w drugiej połowie XIX w. problem z każdą dekadą stawał się coraz poważniejszy. W opracowanych przez Komisję Sprawiedliwości wykazach za 1866 r. podawano, że prowadzono dochodzenia w 136 przypadkach dzieciobójstw, przy czym 38 osób ukarano za bezpośredni czyn dzieciobójstwa, 70 osób za ukrycie porodu, pochowanie ciał dzieci bez wiedzy policji itp. ${ }^{21} \mathrm{~W}$ kolejnych latach liczba porzuceń i zabójstw małych dzieci wzrastała, będąc przede wszystkim problemem ośrodków przemysłowych, gdzie anonimowość zapewniała poczucie bezkarności. Według danych z roku $1898 \mathrm{w}$ guberni piotrkowskiej na wsiach noworodki stanowiły 44\%, w miastach $62 \%$ ogólnej liczby zamordowanych. W Łodzi $70 \%$ morderstw dokonano na noworodkach ${ }^{22}$. Kobietom stawiano również zarzut zatajania śmierci nowo narodzonego dziecka, przy czym pod tym oskarżeniem nie zawsze kryło się posądzenie o jego zabicie. Duża bowiem część kobiet z ubogich grup miejskiej ludności unikała dopełnienia obowiązku zarejestrowania narodzin i okołoporodowej śmierci dziecka. Toteż niemało noworodków, zmarłych w czasie porodu lub tuż po nim, nie było ujętych w ewidencji w aktach stanu cywilnego oraz w księgach parafialnych ${ }^{23}$. Wysokość odsetka nieślubnych narodzin przekładał się bezpośrednio także na wskaźnik śmiertelności niemowląt w wyniku niedostatków opieki, porzuceń i dzieciobójstwa. W wielkich miastach z dużą liczbą słabo zasymilowanych imigrantów, szeroko występującymi patologiami społecznymi i wysoką liczbą urodzeń pozamałżeńskich obserwowany był zarazem najwyższy odsetek umierających dzieci, przede wszystkim noworodków. W lepiej rozwiniętych krajach Europy brak opieki ze strony rodziców był częściowo kompensowany przez opiekę ze strony państwa, co zmniejszało liczbę zgonów najmłodszych dziecii ${ }^{24}$. Za wzór stawiano rozwiązania przyjęte we Francji, gdzie od 1869 r. rozbudowano system zasiłków dla samotnych matek, tak, by mogły same wychowywać dzieci. W Królestwie, przy obojętności i inercji władz, propozycje te były jednak zupełnie nierealne.

Niedostatek przytułków, w których kobiety mogłyby pozostawić dzieci, był jedną z najistotniejszych przyczyn nasilenia porzuceń niemowląt. W Warszawie od $1754 \mathrm{r}$. funkcjonował dom dla podrzutków przy szpitalu Dzieciątka Jezus. Gwałtownie zwiększająca się od lat 40. XIX w. liczba dzieci dostarczanych do przytułku spowodowała, że

21 Wykazy statystyczne sądowo-karne za rok 1866, „Ekonomista” 1868, s. 270-271.

22 I. Ihnatowicz, A. Mączak, B. Zientara, Spoleczeństwo polskie od X do XX wieku, Warszawa 1979, s. 477. Szczegółowo sytuację w Łodzi na przełomie XIX i XX w. omówiła M. Sikorska-Kowalska, Wizerunek kobiety łódzkiej przełomu XIX i XX wieku, Łódź 2001, s. 65-70.

23 E. Kaczyńska, Człowiek..., s. 226.

${ }^{24}$ Fryderyk Sander przytaczał statystykę dotyczącą śmiertelności różnych grup ludności Europy, podkreślając ogromnie wysoką liczbę zgonów niemowląt najbiedniejszych mieszkańców wielkich miast. Na przełomie lat 60. i 70. na 100 żywo urodzonych dzieci w pierwszym roku życia w wybranych krajach europejskich umierało: w Norwegii 10,6, w Anglii i Walii 15,4, we Francji 16,9, w Prusach 21,8, we Włoszech 22, w Austrii 25,8, w Bawarii 31,8, w Wirtembergii 32,9. F. Sander, Zarys nauki o publicznej ochronie zdrowia, przeł. S. Markiewicz, Warszawa 1891, s. 109. Aleksander Mogilnicki na podstawie angielskich statystyk z początku XX w. podawał, że w 1903 r. na 100 dzieci w pierwszym roku życia umierało: w Moskwie 38,6\%, w Petersburgu 28,3\%, w Warszawie 24,3\%, w Budapeszcie 17\%, w Paryżu 15,5\%, w Sztokholmie 15,4\%. A. Mogilnicki, Dziecko i przestępstwo, Warszawa 1916, s. 17. 
zaczęto wprowadzać ograniczenia w ich przyjmowaniu. Zasadniczy przełom przyniosła instrukcja wydana w 1878 r., na mocy której w domu podrzutków mogły być umieszczane dzieci tylko tych kobiet, które co najmniej od roku mieszkały w Warszawie ${ }^{25}$. W przekonaniu części opinii publicznej istnienie ogólnie dostępnych domów dla podrzutków było niemoralne. Niektórzy publicyści przekonywali, że przejmowanie przez instytucje publiczne ciężaru opieki nad dziećmi demoralizuje rodziców, zwalnia ich od odpowiedzialności za utrzymanie i wychowanie potomstwa, przyczynia się do wzrostu liczby nieślubnych urodzeń, daje kobietom możliwość łatwego zarobku w charakterze płatnej mamki ${ }^{26}$. Według wielu ekonomistów koszty prowadzenia domu dla pozbawionych opieki rodzicielskiej dzieci były zbyt wysokie, co miało usprawiedliwiać wprowadzenie limitów przyjmowania podrzutków ${ }^{27}$. W rezultacie zdecydowana większość kobiet, które znalazły się w Warszawie, będąc w ciąży, ale przebywając w mieście bez zameldowania, nie mogła liczyć na wsparcie w opiece nad dzieckiem. Wywołało to wzrost przypadków dzieciobójstwa i porzucania dzieci w miejscach publicznych. W innych miastach Królestwa również nie istniały domy dla niemowląt, w których matki mogłyby je pozostawić ${ }^{28}$. Toteż można przyjąć, że sformalizowanie zasad przyjmowania dzieci do domu podrzutków w Warszawie i drastyczne ograniczenia w tym zakresie oraz brak odpowiednich zakładów opiekuńczych w innych miastach przyczyniły się do zwiększenia liczby dzieciobójstw, śmiertelności zaniedbanych dzieci, a także rozpowszechnienia indywidualnej opieki nad niemowlętami ze strony płatnych opiekunek.

Poddanie dodatkowym obostrzeniom zasad przyjmowania dzieci do przytułku dla opuszczonych niemowląt wywołało dyskusję w prasie. Wielu ówczesnych obserwatorów życia społecznego podkreślało niekorzystny wpływ restrykcyjnych przepisów ${ }^{29}$. Na łamach „Niwy” w 1879 r. pisano, że ,zapobieganie nieprawym urodzinom jest niewątpliwie ważnym i pięknym zadaniem społecznych instytucyi, ale do rzędu ich nie należy

25 E. Mazur, Dobroczynność w Warszawie XIX wieku, Warszawa 1999, s. 82.

${ }^{26}$ R. Buczyński, op. cit., t. I, s. 144.

27 Zob. cztery artykuły dotyczące domu podrzutków i opieki nad opuszczonymi dziećmi autorstwa L. Paprockiego w „Ekonomiście” 1871, nr 1-4.

${ }^{28}$ Brak przytułków był szeroko komentowany w prasie lokalnej. W Łodzi kwestię tę poruszano np. w „Rozwoju” i „Dzienniku Łódzkim”, na łamach którego w 1886 r. pisano: „Brak przytułku dla podrzutków daje się bardzo silnie uczuwać w Łodzi. Ileż to razy policya znajduje trupy dzieci podrzuconych pod parkanami, na placach, na ulicach i w tym podobnych miejscach. Jeżeli zaś znajdzie żywe dziecko, wtedy nie wiedzieć co z niem robić. W tych dniach np. zdarzyło się, iż pewnej kobiecie podrzucono podedrzwiami dziecko, matkę którego jednak udało się policji znaleźć. Lecz cóż z tego, kiedy matka nie chciała wziąć do siebie, thumacząc się tem, iż sama nie ma pokarmu, a na najęcie mamki lub też na sztuczne karmienie środki jej nie pozwalają. Co robić w takim razie z dzieckiem? Gdyby istniały domy dla podrzutków, można by tam dziecko oddać, ponieważ jednak niczego podobnego nie ma w Łodzi, nie wiadomo co się z dzieckiem stanie. Sprawę powyższą podajemy tu dla wiadomości osób, którym dobro bliźnich leży na sercu”. Równie dramatyczna sytuacja miała miejsce w innych miastach Królestwa. Dr J. Pietrasiewicz pisał w 1903 r. o Częstochowie: „Z potrzeb naszego miasta, stojących w bardzo bliskim związku z istnieniem przytułku [położniczego - przyp. A.B.], wymienię potrzebę domu wychowawczego dla niemowląt. Wiele, bardzo wiele dzieci, urodzonych u nas w Częstochowie, ginie wprost z powodu braku opieki. Dom wychowawczy wpłynąłby bez wątpienia na zmniejszenie śmiertelności niemowląt i przez to przyniósłby niewypowiedzianą korzyść społeczną". J. Pietrasiewicz, Sprawozdanie z działalności przytułku położniczego w Częstochowie za rok 1902, „Medycyna” 1903, s. 564.

29 B. Prus, op. cit., t. III, s. 253. 
bynajmniej dom podrzutków [...] Istnienie domów podrzutków nie wpływa wcale na ilość rodzących się nieprawych dzieci - to rzecz zbyt dobrze znana i udowodniona statystycznie. Dom podrzutków natomiast, zapobiega ulicznemu podrzucaniu i dzieciobójstwu, tym ohydnym zbrodniom wyradzającym wiele innych. Zamknięcie takiego domu, lub zamurowanie kółka nie poprawi niczyjej moralności" ${ }^{30}$.

W licznych publikacjach postulowano przede wszystkim stworzenie instytucji, w której ubogie matki po porodzie mogłyby przebywać wraz z dziećmi. Z entuzjazmem przyjęto powołanie w 1885 r. w Warszawie, z inicjatywy lekarzy, prawników i filantropów, Towarzystwa Opieki nad Ubogimi Matkami i ich Dziećmi. Towarzystwo założyło przytułek dla położnic i niemowląt, w którym przyjmowano zarówno chrześcijanki, jak i żydówki. Celem organizacji była opieka nad kobietami w czasie ciąży, porodu i połogu, opieka nad niemowlętami, ale także działalność wychowawcza wobec kobiet i przygotowanie ich do podjęcia pracy ${ }^{31}$. Brak odpowiednich funduszy nie pozwalał jednak rozszerzyć działalności Towarzystwa. Nie było ono w stanie zastąpić finansowanego przez administrację państwową zakładu dla dzieci najuboższych matek. Ale po 1864 r. władze rosyjskie całkowicie lekceważyły problematykę higieny, zdrowia i opieki społecznej w Królestwie Polskim. Niski poziom opieki zdrowotnej i społecznej był konsekwencją zarówno zacofania Rosji i jej polityki leseferyzmu w tym zakresie, jak i celowego działania zaborcy wobec Polaków. Skrajne zaniedbania w tych dziedzinach życia społecznego były formą represji politycznych po powstaniu styczniowym. W niewielkim stopniu poprawiały sytuację nieliczne przytułki położnicze, które zapewniały opiekę ubogim kobietom w czasie porodu i pierwszych dni połogu ${ }^{32}$. Oczywiście miało to ogromne znaczenie dla bezdomnych kobiet, które zyskiwały podstawową opiekę. Wiele ubogich kobiet nadal rodziło w przypadkowych miejscach; działacze społeczni, apelując o zakładanie przytułków, pisali z ironią o ,uroczystej chwili przybycia na świat w zimnem, nieopalonem podstryszu, wszelkich pozbawionem wygód i możności zaspokojenia niezbędnych dla matki i dziecięcia potrzeb"33. Takie warunki porodu musiały wpływać na psychofizyczny stan położnicy, wynędzniałej i pozbawionej opieki. Część zdesperowanych kobiet dopuszczała się dzieciobójstwa zaraz po porodzie. Kobiety rodzące w przytułku znajdowały się w lepszej sytuacji, ale opuszczając go wkrótce po rozwiązaniu, również w wielu wypadkach nie były w stanie lub nie chciały zająć się dzieckiem, co prowadziło do porzucenia go.

\footnotetext{
30 Sprawy bieżace. W sprawie domu podrzutków, „Niwa” 1879, t. 15, s. 67-68.

31 A. Moldenhaver, O opiece u nas nad dziećmi, Warszawa 1890, s. 10-12 i n.

${ }^{32} \mathrm{O}$ działalności przytułków położniczych zob. m.in. Ustawa Towarzystwa opieki na ubogiemi matkami oraz ich dziećmi w Warszawie, „Medycyna” 1885, s. 249-253; Gromadzki, Przytułek dla rodzacych nr 4 na Pradze i jego dotychczasowa działalność, „Medycyna” 1885, s. 337-342; J. Rogowicz, Nowe zakłady publiczne (przytutki) dla biednych rodzacych w Warszawie, „Medycyna” 1885, s. 575, 591-596, 607-612, 623-627, 639-643; J. Rogowicz, Przytulki dla biednych rodzacych w Warszawie, „Medycyna” 1896, s. 354-358, 380-385, 412-414, 436-439; J. Pietrasiewicz, op. cit., s. 544-545, 560-564; Otwarcie nowego przytułku położniczego miejskiego, „Zdrowie” 1913, s. 56-57; J. Sosnowska, Działalność socjalna i opiekuńczo-wychowawcza Łódzkiego Chrześcijańskiego Towarzystwa Dobroczynności (1885-1940), Łódź 2011, s. 160-177; E. Mazur, op. cit., s. 98-100; Z. Podgórska-Klawe, Szpitale warszawskie 1388-1945, Warszawa 1975, s. 231-233.

${ }^{33}$ Niedole dziecięce, Warszawa 1882, s. 9.
} 
W sytuacji, kiedy istniejące zinstytucjonalizowane formy opieki nad ubogimi matkami i ich dziećmi były w stanie zapewnić pomoc zaledwie niewielkiej części potrzebujących, nastąpiło rozwinięcie prywatnych form opieki - czy raczej pseudoopieki nad niemowlętami. Zajmowały się tym kobiety, które za niewielką opłatą przyjmowały dziecko „,na garnuszek”. Już w połowie XIX w., a zapewne i wcześniej, istniały w Warszawie miejsca, w których oddawano dzieci opiekunkom, ale dopiero w ostatnim dwudziestoleciu XIX w. proceder ten rozwinął się na nieznaną wcześniej skalę. W dobie industrializacji większość wielkich europejskich miast spotykała się z problemem porzucania niechcianych dzieci lub powierzania ich pod opiekę najemnych opiekunek, które zyskały wymowne miano „fabrykantek aniołków”; polskie określenie było tłumaczeniem zwrotu zapożyczonego z języka niemieckiego: Engelmacherin ${ }^{34}$. Szansa przeżycia dziecka była niemal żadna. Nie mogło być inaczej, skoro jedna opiekunka przyjmowała jednorazowo kilkoro dzieci, które przebywały w zagrzybionych mieszkaniach, znajdujących się na poddaszach i w suterenach, a środki przekazywane na utrzymanie niemowlęcia nie wystarczały na najbardziej skromne wyżywienie. Po kilku tygodniach wynędzniałe i chore dziecko, pozbawione wystarczającej ilości pożywienia, przetrzymywane w zawilgoconych, nieogrzewanych pomieszczeniach umierało ${ }^{35}$. Dzieci, które miały legalne metryki, chowano na cmentarzach, większość nie była ujęta w żadnej ewidencji. W takich wypadkach ciała porzucano w publicznych miejscach lub zakopywano; zdarzały się także przypadki palenia zwłok dzieci. W krajach zachodnioeuropejskich w drugiej połowie XIX w. wydawano regulacje prawne, określające warunki, jakie musiała spełnić osoba, przyjmująca za opłatą dzieci pod opiekę; w Anglii stosowne przepisy wprowadzono w 1872 r., pod nazwą Infant Life Protection $\mathrm{Act}^{36}$. W Królestwie takich przepisów nie było.

Co kilka, kilkanaście lat wybuchała sprawa poruszająca skalą zbrodni. Ujawniane przypadki oskarżanych o zaniedbania i dzieciobójstwa „fabrykantek aniołków” miały miejsce przede wszystkim w najbardziej uprzemysłowionych guberniach - warszawskiej i piotrkowskiej ${ }^{37}$. Najbardziej głośnymi procesami dotyczącymi zorganizowanego dzieciobójstwa były sprawy Wiktorii Szyfersowej z 1880 r. i Marianny Skublińskiej z 1890 r. ${ }^{38}$ Każda z kobiet w Warszawie przez lata przy pomocy wspólników trudniła się opieką nad niemowlętami, każda odpowiadała za śmierć dziesiątek dzieci. Podobną praktykę

${ }^{34}$ A. Moldenhaver, op. cit., s. 10; M. Kurkowska, ,Fabrykantki aniołków”. O problemie aborcji w Polsce w latach 1878-1939, „Arcana” 1998, z. 1, s. 163.

35 A. Bołdyrew, ,Fabrykantki aniołków” w wielkoprzemysłowym pejzażu Europy u schyłku XIX w., w: Zabijać $i$ umierać. Aspekty społeczno-kulturowe, red. B. Płonka-Syroka, A. Szlagowska, Wrocław 2010, s. $107-118$.

36 S. Markiewicz, Kantory mamek i karmicielki płatne, w: Niedole dziecięce, s. 116.

37 [Poseł Prawdy], Liberum veto, „Prawda”, 1892, s. 57.

38 „Najjaskrawszym przecie objawem dzielności naszego cywilizacyjnego pochodu jest ów tragiczny dom komisowo-ekspedycyjny pod firmą: Marianna Szymczak, Jan Stępniak et Comp., który trudnił się zabijaniem dzieci. [...] Za nimi - widzimy legion akuszerek, a za tymi - legiony legionów zbydlęconych ojców, okrutnych, biednych i serca pozbawionych matek - i - bezwstydnych czy nieszczęśliwych dziewic. Cała ta armia istot niezupełnych, spodlonych, głupich i nędznych to właściwa fabryka ogromnego występku. [...] Tak się urządza proletariat bez środków i bez Boga [...] Olbrzymi nacisk sądów i policji ledwie zdoła utrzymać w karbach tę lawinę dzikości, w której dzisiejsza cywilizacja zatonąć by mogła. Takie są skutki niezajmowania się maluczkimi!...”. B. Prus, Kroniki, t. IV, s. 227. 
prowadziło wiele innych kobiet, m.in. Wiktoria Wypyska, Antonina Gencel, Karolina Ostrouszko, Józefa Neumanowa, Marcjanna Brzeszczakowa, w Łodzi niejaka Bednarkowa ${ }^{39}$.

Pozostawianie dzieci pod opieką ,fabrykantek aniołków” było spowodowane w znacznej mierze tym, że duża część kobiet po porodzie podejmowała pracę w charakterze mamki w zamożnej rodzinie. Zapotrzebowanie na tego rodzaju pracę było bardzo duże, a wynagrodzenie mamki wyższe niż pensja służącej. Przez cały XIX wiek mimo postulatów lekarzy i pedagogów, w większości domów ziemiańskich i burżuazyjnych zatrudniano dla dzieci karmicielki. Nie zmienił tego stanu rzeczy i początek XX w. W prasie i poradnikach dla kobiet, czasopismach społeczno-kulturalnych i fachowych coraz częściej poruszano kwestię „mamczarstwa”, uznając ją za poważny problem społeczny ${ }^{40}$. Obyczaj zatrudniania mamek krytykowało wielu lekarzy i pedagogów, uważając to za przejaw egoizmu kobiet z zamożnych środowisk i symbol wykorzystywania przez bogatych fatalnego położenia kobiet z miejskiej i wiejskiej biedoty. Pisali o tym m.in. Iza Moszczeńska i Janusz Korczak ${ }^{41}$. Zwracano uwagę na tragiczny los dzieci mamek oraz moralny upadek ich samych. Opinia publiczna aprobowała jednak taki model opieki nad dzieckiem w domach elit; zatrudnianie mamki było w wielu kręgach wręcz czynnikiem dodającym rodzinie prestiżu.

Zwyczaj zatrudniania mamek wywierał istotny wpływ na skalę dzieciobójstwa i porzuceń dzieci. Do dużego miasta nierzadko przybywały młode kobiety spodziewające się dziecka, namówione do tego przez stręczycielkę. Wiele z nich wierzyło zapewnieniom zdobycia łatwej i popłatnej pracy w charakterze karmicielki; właścicielki kantorów przekonywały także o zapewnieniu dobrej opieki dla niemowlęcia. Kobiety rodziły dziecko pod opieką akuszerki; żeby uiścić opłatę za poród, musiały znaleźć pracę. Zatrudnienie się do karmienia cudzego niemowlęcia było najprostszym rozwiązaniem, zapewniającym uregulowanie należności i opłacenie opieki nad dzieckiem. Pozostawiając je w domu „fabrykantki aniołów”, nie zawsze zapewne zdawały sobie sprawę z jego położenia. Konieczność rozstania z dzieckiem dla części kobiet była trudnym doświadczeniem, a jego

\footnotetext{
39 Ibidem, s. 381, t. VI, s. 319; „Niwa” 1890, nr 5, s. 79; „Zdrowie” 1890, s. 65; „Kłosy” 1890, s. 327; „Kłosy” 1890, 356-358; S. Milewski, Ciemne sprawy dawnych warszawiaków, Warszawa 1982, s. 120-160; K. Beylin, Dni powszednie Warszawy w latach 1880-1900, Warszawa 1967, s. 289-290.

40 J. Bączkiewicz, O żywieniu niemowląt, Warszawa 1903, s. 60-66; Z. Srebrny, Kronika, „Medycyna” 1904, nr 32, s. 682-683; [M. Warszawski] streszczenie, Budin, Mace, Wady serca i karmienie, „Kronika Lekarska" 1902, s. 750. Jednocześnie nawet w profesjonalnych pismach lekarskich na przełomie XIX i XX w. w przypadku niemożności karmienia dziecka przez matkę często polecano zatrudnienie mamki, uznając to za optymalne rozwiązanie. Zob. np. A. Monti, Trawienie i naturalne odżywianie osesków, „Przegląd Lekarski” 1897, R. XXXVI, nr 12, s. 150.

${ }^{41}$ I. Moszczeńska, Mamczarstwo: kwestia hygieniczno-etyczna, „Głos” 1900, nr 48, s. 761; I. Moszczeńska, Fabrykacja aniołków, „Głos” 1898, nr 40, s. 949; Z. Bychowski, „Głos” 1900, s. 827-828; Zjawisko wynajmowania mamek istniało i w okresie dwudziestolecia międzywojennego. W 1920 r. o szkodliwości odmowy karmienia dzieci przez kobiety z zamożnych rodzin i zatrudnianiu mamek pisał Janusz Korczak. „Prostytucja, która służy na użytek mężczyzn, znajduje swe dopełnienie społeczne w mamczarstwie na użytek kobiety. Należy mieć pełną świadomość uświęconej krwawej zbrodni na biednym dziecku [...]”. J. Korczak, Jak kochać dziecko, Warszawa b.r.w., s. 21. Zob. także J. Śmiarowska, Higjena kobiety we wszystkich okresach jej życia, Lwów 1925, s, 137.
} 
rychła śmierć dramatem. Prowadziło to do moralnego znieczulenia mamek, które karmiąc cudze dziecko, musiały przeboleć stratę własnego.

Przekazy źródłowe pokazują i drugie, częściej spotykane oblicze „mamczarstwa”. Pisano, że mamki bez żalu przyjmowały śmierć swego dziecka, zwalniającą z konieczności opłat pobieranych przez opiekunkę. W istocie zresztą kobiety zazwyczaj nie miały złudzeń co do przyszłości dziecka, zwłaszcza gdy nie po raz pierwszy podejmowały pracę w charakterze mamki. Wybitny działacz społeczny, lekarz i higienista Stanisław Markiewicz pisał: „Osoba oddająca niemowlę, wie doskonale, że je oddaje kobiecie ubogiej, że niemowlę będzie się mieścić w izbie ciemnej, wilgotnej, zadusznej, że leżeć będzie do spółki - z drugiem i trzeciem, równie nieszczęśliwem biedactwem, w jednym koszyku, że o kąpieli nie może być dlań mowy i że kobieta niemowlę przyjmująca, bynajmniej piersią karmić go nie może, krów własnych nie trzyma, a zapłatę bierze taką, iż o kupowaniu dobrego mleka dla niemowlęcia nie może myśleć. Tak więc, oddanie niemowlęcia płatnej karmicielce przez pośredniczącą akuszerkę lub przez samę matkę następuje na skutek milczącego, wzajemnego pomiędzy niemi porozumienia co do koniecznych niedostatków, wśród których niemowlę żyć będzie i wśród których, niestety, umrzeć musi. Oszukanej ani oszukującej tu nie ma. W ocalenie niemowlęcia najczęściej, tak oddająca, jak i przyjmująca, nie wierzą, i dlatego też usiłowań w tym kierunku nie robią żadnych" ${ }^{2}$. W pamiętnikach podkreślano brak skrupułów, cynizm, wyrachowanie, demoralizację mamek, szukanie przez nie łatwego zarobku, rzadko zdobywając się wobec nich na współczucie ${ }^{43}$. „Występne czy nieszczęśliwe, czasami oszukane tylko haniebnie”44 po wykarmieniu dziecka zachodziły w kolejną ciążę, by po porodzie znów znaleźć zatrudnienie. Część z nich zapewne decydowała się na porzucenie własnego dziecka w miejscu publicznym, co niekoniecznie należy odczytywać jako przejaw bezduszności. Mając wiedzę na temat warunków, w jakich przebywały niemowlęta pod opieką „fabrykantek aniołków”, mogły mieć nadzieję na lepszy los dziecka, pozostawionego w miejscu, gdzie mogło szybko zostać odnalezione i ocalone od śmierci. Niemowlęta były porzucane w bramach, kościołach, parkach, przed szpitalami i przytułkami. Zdarzały się także przypadki umieszczenia kosza z niemowlęciem w pociągu czy karecie zamożnej damy ${ }^{45}$. Najbardziej zdeprawowane czy zdesperowane zabijały nowo narodzone dzieci; zbrodnie takie były stałą częścią XIX-wiecznego krajobrazu życia społecznego ${ }^{46}$. W codziennej

42 S. Markiewicz, op. cit., s. 116. Zob. także A. Moldenhawer, op. cit., s. 30.

43 A. Bołdyrew, Matka i dziecko w rodzinie polskiej. Ewolucja modelu życia rodzinnego w latach 1795-1918, Warszawa 2008, s. 72-73.

44 A. Moldenhawer, op. cit., s. 23.

45 B. Prus, op. cit., t. VII, s. 240.

46 „Dzieciobójstwo spełniane bywa najczęściej na dziecku, pochodzącem z nieprawych związków, wkrótce po jego urodzeniu. Położenie niezamężnej matki jest częstokroć okropne. Opuszczona przez mężczyznę, rzucona na pastwę nędzy i wstydu, czując się związaną z dzieckiem, którego nie ma za co wychować, a które przeszkadza jej współcześnie do wszelkich rodzaju zarobku - nie dziw, że kobieta taka, przeszedłszy wszystkie stopnie rozpaczy i nędzy, przy fatalnym zbiegu okoliczności, pozbywa się tego dziecka, które jej tylko ciężarem się stało i spełnia dzieciobójstwo”. Kronika kryminalna. Dzieciobójstwo, „Gazeta Sądowa Warszawska”, 1875 , s. 77. 
prasie bez trudu znaleźć można było informacje o znalezieniu ciał dzieci - utopionych, otrutych, uduszonych, wrzuconych do publicznej kloaki ${ }^{47}$.

Prócz czynników o charakterze ekonomicznych na skalę dzieciobójstwa i porzucania dzieci wpływały kwestie natury obyczajowej. Na przestrzeni całego XIX w. dyskryminowano nieślubne matki i ich potomstwo. W kręgach elit nieślubne macierzyństwo w XIX i na początku XX w. nadal postrzegane było w kategoriach hańby. Jeśli legalne potomstwo było uznawane za przyszłość narodu, gwarancję stabilności i trwałości, to dzieci nieślubne uważano za zagrożenie społecznego ładu, dowód deprawacji, sprzeniewierzenie się zasadom. Pozamałżeńskie macierzyństwo stanowiło antywzorzec życia rodzinnego, skazywało matkę i dziecko na ostracyzm i potępienie w środowisku rodzinnym i towarzyskim, wywoływało skandal, o którym pamiętano przez wiele lat. Nieślubne dziecko kompromitowało całą rodzinę, brukało jej honor, obniżało społeczną pozycję. W kulturze ludowej nieślubne macierzyństwo wywoływało potępienie, budziło solidarną krytykę lokalnej społeczności, obawiającej się swobody seksualnej, mogącej destabilizować ład wspólnoty. „Panny z dzieckiem” były przedmiotem kpin, szyderstw, poniżeń, czasem zmuszano je do wykonywania określonych, upokarzających czynności. Pogardliwy stosunek do nieślubnych matek i ich dzieci wyrażano także w warstwie słownej. Kobiety nazywano przespankami, przeskoczkami, skoczkami, zawitkami, goniochami, polatuchami, wytrzyjkątami, słomianymi pannami. Dzieci z nieprawego łoża określano mianem bękart, bąk, znajda, znajdor, ten bez ojca, ławczak, pokrzywnik. Nieślubne macierzyństwo było długo komentowane i pamiętane w środowisku, a dziecku przez całe życie towarzyszyło piętno nieprawego pochodzenia ${ }^{48}$. Zazwyczaj w środowisku włościan i drobnej szlachty nieślubna matka i dziecko tylko przejściowo były usuwane na margines społeczności, kobieta często wychodziła za mąż za mężczyznę znacznie starszego od siebie, np. wdowca z kilkorgiem dzieci ${ }^{49}$. Jednak w wielu wypadkach kobieta spodziewająca się nieślubnego dziecka miała prawo obawiać się szykan otoczenia. Z pewnością przyczyniało się to do prób zatajenia ciąży, a po rozwiązaniu porzucenia dziecka, co zazwyczaj łączyło się z opuszczeniem rodzimego środowiska.

Deprecjonowanie dzieci nieślubnych było jednym z powodów, dla których kobiety nie chciały podejmować trudu zatrzymania i wychowania dziecka. Często o tym problemie pisali publicyści, przypisując być może kwestii wstydu i obawy matek przed utratą dobrego imienia znaczenie zbyt duże. Jeśli bowiem kobietom z elitarnych grup z powodu posiadania nieprawego potomstwa $\mathrm{z}$ całą pewnością groziło napiętnowanie, to $\mathrm{w}$ środowiskach ludowych, jak wspomniano, nieślubne macierzyństwo nie wywoływało aż takiego skandalu. W ubogich dzielnicach miast, jak zaznaczono, związki pozamałżeńskie i dzieci nieślubne nie należały do rzadkości. Dzieci takie raczej nie stawały się obiektami upokorzeń ze strony otoczenia. Uwiedzenie stawało się banalne przez swą powszech-

47 Zob. m.in. liczne informacje w latach 80. XIX w. na łamach „Kuriera Warszawskiego” czy „Dziennika Łódzkiego".

48 M. Wieruszewska, Kontrola społeczna prokreatywnej funkcji rodziny $w$ świetle badań wsi betchatowskiej, „Łódzkie Studia Etnograficzne” 1970, t. XII, s. 53-54; Cz. Kępski, Dziecko sieroce i opieka nad nim w Polsce w okresie międzywojennym, Lublin 1991, s. 21.

49 T. Krawczak, W szlacheckim zaścianku, Warszawa 1993, s. 215-216. 
ność, codziennością były związki na zasadzie konkubinatu. Nieślubnym matkom nie dokuczało odium otoczenia, ale bieda, która wiele z nich zmuszała do oddania dziecka do przytułku lub pod opiekę nędznie opłacanych opiekunek.

W wyższych grupach społecznych kobiety spodziewające się nieślubnego dziecka próbowały zataić ciążę, będącą jawnym dowodem seksualnego występku, niedopuszczalnego w tej grupie społecznej. Trudno określić, jak często uciekano się do aborcji, zjawiska tabuizowanego do tego stopnia, że trudno znaleźć informacje w pamiętnikach, dziennikach i listach. O tym, że były dokonywane, i to wcale nierzadko, świadczą wypowiedzi lekarzy, publikowane na lamach prasy fachowej. Drugim praktykowanym sposobem uniknięcia skandalu było potajemne urodzenie dziecka. Część kobiet z wyższych kręgów społecznych, chcąc ukryć pozamałżeńską ciążę, wyjeżdżało na czas jej ostatniego trymestru i rozwiązania za granicę ${ }^{50}$. Kobiety niemające środków pozwalających na wjazd za granicę, korzystały z usług prywatnych zakładów lekarskich i akuszeryjnych w dużych miastach $^{51}$. Po rozwiązaniu umieszczano nieprawe dziecko w wiejskiej rodzinie, dla której zajęcie się ,pańskim bękartem” było dodatkowym źródłem dochodu. Mimo bez wątpienia patologicznego charakteru tego rodzaju rozwiązań trzeba podkreślić, że było to zupełnie innego rodzaju porzucenie; raczej emocjonalne odrzucenie, odmówienie uznania dziecka, ale nie dążenie do jego fizycznej eliminacji. Niski poziom higieny w chłopskich rodzinach przyjmujących dzieci powodował, iż niemało z nich umierało, mimo to miały one większą szansę, by przeżyć, niż dzieci znajdujące się pod opieką „fabrykantek aniołków".

Trzeba jednak zaznaczyć, że liczba niemowląt oddawanych na wychowanie wiejskim rodzinom przez rodziców z wyższych grup społecznych nie była duża. Również w przypadku dzieci porzucanych w miejscach publicznych bardzo rzadko zdarzały się niemowlęta ubrane w dostatnie i czyste ubrania, umieszczone w beciku, do którego dołączany był krótki liścik z prośbą o zajęcie się dzieckiem, choć i takie informacje można znaleźć w prasie. Rzadko były to więc dzieci, będące „owocem grzechu” kobiet z wyższych grup, które z powodu ,panieńskiego wstydu” decydowały się na desperacki krok. Szukając odpowiedzi na pytanie, kim były matki dzieci porzucanych w schludnym kaftaniku należy być może wskazać choćby na guwernantki, uwiedzione przez pracodawcę, jego syna lub znajomego. Romans, często z obietnicą małżeństwa kończył się w momencie, gdy kobieta spodziewała się dziecka. Zazwyczaj wyrzucano ją z domu, w którym praco-

50 W szpitalu w Wiedniu w 1881 r. urodziła swe nieślubne dziecko Gabriela Zapolska. Przyszła pisarka pozostawała w tym czasie w związku małżeńskim z Konstantym Śnieżko-Błockim, ojcem dziecka był Marian Gawalewicz, kierownik amatorskiego teatru warszawskiego Towarzystwa Dobroczynności, w którym występowała Zapolska. Oczekującą dziecka kobietę umieszczono w klasztorze Panien Wizytek w Warszawie, po czym przewieziono do wiedeńskiej kliniki. Dziecko oddane na wychowanie na wieś wkrótce zmarło. G. Zapolska, Listy, t. I, opr. S. Linowska, Warszawa 1970, s. 123.

51 Interesujących informacji dostarczają anonse w prasie, jak umieszczony w $1898 \mathrm{r}$. na łamach wydawanego w Piotrkowie „Tygodnia”: „Akuszerka z dyplomem warszawskiego uniwersytetu udziela porad paniom, potrzebującym zupełnej dyskrecji, zaopatrzona w utensylija, zabezpieczające zdrowie chorych. Przyjmuje na czas dłuższy bez meldunku. Umieści dziecię. Pokoje oddzielne, wspólne, wygodne. Cena przystępna. Królewska 31, wprost Saskiego Ogrodu”. „Tydzień” 1898, nr 30, s. 4. 
wała, co prowadziło czasem do podjęcia próby samobójczej, czasem do dzieciobójstwa lub porzucenia dziecka ${ }^{52}$.

W szczególnie trudnym położeniu znajdowały się proste służące. Pozbawione wsparcia własnej rodziny, przebywające ciągle w domu pracodawców, z którymi nic ich nie łączyło, łatwo padały ofiarą uwiedzenia. W przypadku ciąży służącą oskarżano o rozpustę i wyuzdanie ${ }^{53}$. B. Prus o sytuacji porzuconej kobiety pisał: „Do cierpień macierzyństwa dodają jej udręczenie i hańbę, zmuszają do ostatecznego spodlenia, podczas gdy jej wspólnik - chodzi po mieście z rękoma w kieszeni i zadartą głową"54. Po porodzie kobieta zazwyczaj decydowała się na oddanie dziecka płatnej opiekunce lub porzucała je; służąca z dzieckiem nie miała bowiem żadnych szans na znalezienie pracy. Społeczna reakcja na problem nieprawych urodzeń pozostała podobna do I wojny światowej, a w znacznej mierze także w okresie międzywojennym ${ }^{55}$. Moralność wyższych grup społecznych pozostawała niezmiennie surowa wobec problemu nieślubnego macierzyństwa, uważając je za dowód demoralizacji niższych grup, prymitywnego seksualizmu i rozwiązłości.

Do utrwalania deprecjonowania dzieci pozamałżeńskich przyczyniły się przepisy prawa cywilnego, autoryzujące prawne upośledzenie dzieci nieślubnych. Tradycyjna niechęć została usankcjonowana w majestacie prawa, co miało wpływ na marginalizowanie dzieci nieślubnych w każdej grupie społecznej, a w pewnym stopniu zapewne na odrzucenie przez matki. Formalnoprawna dyskryminacja znalazła odzwierciedlenie w każdym z trzech ustanowionych na przełomie XVIII i XIX w. kodeksów cywilnych, obowiązujących na przestrzeni XIX stulecia na obszarze ziem polskich. W największym stopniu dzieci z nieprawego łoża były deprecjonowane na obszarze Księstwa Warszawskiego, później Królestwa Polskiego, na mocy przepisów zawartych w I księdze Kodeksu Napoleona $^{56}$. Stojąc na straży legalnej rodziny, Kodeks w art. 340 wprowadzał zakaz poszukiwania ojcostwa, co miało chronić spokój funkcjonującego w majestacie prawa ogniska domowego. Surowe zapisy dotyczące dzieci nieślubnych uległy pewnemu złagodzeniu po reformie prawa cywilnego w Królestwie Polskim i wprowadzeniu w 1825 r. Kodeksu Cywilnego Królestwa Polskiego ${ }^{57}$. Mimo względnej poprawy położenia dziecka z niepra-

${ }^{52} \mathrm{~W}$ literaturze pięknej i prasie codziennej przedstawiano wiele historii uwiedzenia i jego dramatycznych konsekwencji w postaci dzieciobójstwa lub porzucenia dziecka. Warszawski pisarz i adwokat Henryk Nagiel w wydanej po raz pierwszy w 1888 r. powieści „Tajemnice Nalewek” pisał o przygarniętej przez agenta policyjnego dziewczynie, jako o typowej miejskiej „,karierze”: „Historia dziewczyny była bardzo prosta. Pozostawała w zamożnym domu w charakterze guwernantki. Niedoświadczona, młoda, padła ofiarą eleganckiego młodzieńca, kuzyna pani domu. W chwili, kiedy się wszystko wydało, kiedy miała zostać matką, ze zgrozą wypędzono ją ze świętobliwego domu. Gdzieś na poddaszu urodziła dziecko, które w dwa dni potem znaleziono zakopane na podwórzu. Twierdziła, że dziecko urodziło się nieżywe" H. Nagiel, Tajemnice Nalewek, Warszawa 1911, s. 107; E. Sawicka, Henryk Nagiel i tajemnice Nalewek, w: J. Kulczycka-Saloni, E. Ihnatowicz (red.), Warszawa pozytywistów, Warszawa 1992, s. 101-102.

53 W. Chodecki, Co pcha stużące w objęcia prostytucyi, „Zdrowie” 1906, s. 565.

${ }^{54}$ B. Prus, op. cit., t. XI, s. 45.

55 Por. Cz. Kępski, op. cit., s. 20.

${ }^{56}$ Kodeks cywilny francuski (Kodeks Napoleona), Warszawa 1807, passim.

57 Jednym z najważniejszych nowych postanowień w ramach prawa rodzinnego była względna poprawa uprawnień dzieci nieślubnych. M.in. na wzór ustawodawstwa pruskiego i austriackiego wyznaczono możli- 
wego łoża nadal było ono dyskryminowane. W podobny sposób nierówne traktowanie potomstwa przejawiało się w prawie zwyczajowym; głównym przejawem marginalizowania pozycji nieślubnych dzieci były dysproporcje w prerogatywach spadkowych. Największym jednak problemem pozostawał zakaz poszukiwania ojca, a co za tym idzie, brak możliwości wystąpienia o alimenty, co z pewnością także przyczyniało się do porzucania dzieci przez matki. Praktyka sądowa łagodziła nieco bezwzględność zapisów kodeksu, ale sądowe dochodzenie alimentów dla nieślubnego dziecka i jego matki zdarzało się niesłychanie rzadko.

Na przełomie XIX i XX w. w publicystyce Królestwa pojawiło się wiele głosów, dotyczących konieczności zmiany stosunku opinii publicznej do dzieci, traktowanych jako cenny kapitał społeczny. W coraz większym stopniu dostrzegano wartość młodego pokolenia, w tym także dzieci nieślubnych ${ }^{58}$. W kategoriach społecznego imperatywu zaczęto traktować konieczność troski o zachowanie dzieci przy życiu, a później zapewnienie im zdrowia i właściwego wychowania, za konieczną uznawano opiekę nad nimi ze strony państwa. Jednym z ważnych aspektów tych działań miało być zmniejszenie skali dzieciobójstwa i porzuceń dzieci. Prawnicy, lekarze, pedagodzy, społecznicy na łamach prasy zwracali uwagę na konieczność zmiany stosunku społeczeństwa do nieślubnych matek i ich dzieci. Pisano o konieczności modernizacji prawnej, postulowano liberalizację przepisów wobec niezamężnych kobiet, dopuszczających się dzieciobójstwa i wprowadzenia do kodeksu karnego pojęcia przestępstwa uprzywilejowanego (delictum privilegatum $)^{59}$. Wielu publicystów przekonywało, że konieczna jest zmiana przepisów prawa karnego wobec dzieciobójczyń i stosowanie wobec nich łagodniejszych kar, uwzględniających okoliczności, w których znalazła się kobieta, doświadczająca pogardy otoczenia, przeżywająca hańbę z racji nieślubnej ciąży ${ }^{60}$. Działania te powoli zmieniały stosunek postępowej części opinii publicznej do problemu nieślubnych dzieci i ich matek; na przełomie XIX i XX w. można zauważyć zmianę mentalności i wrażliwości spo-

wość uznania dziecka naturalnego na mocy aktu władcy na prośbę ojca lub obojga rodziców (art. 296). Zdobycie statusu uznanego dziecka nie wymagało odrębnego potwierdzenia tego stanu przez rodziców, jeśli zawarli oni związek małżeński po jego narodzinach (art. 291). Artykuł 303 Kodeksu Cywilnego Królestwa Polskiego nakładał na rodziców obowiązek żywienia i wychowania dzieci nieślubnych, także wówczas, gdy nie mogły one być uznane, pochodząc ze związków cudzołożnych i kazirodczych. Ibidem, s. 506.

${ }^{58} \mathrm{~W}$ wielu publikacjach nadal pisano o niekorzystnym wpływie na społeczeństwo nieślubnych dzieci, wywodzących się ze „dysgenicznych” środowisk. W. Chodecki, pisząc o degenerującym wpływie alkoholu, podkreślał sytuację dzieci nieprawego pochodzenia i ich niekorzystną rolę w społeczeństwie: „Alkohol zadaje potężne ciosy ustrojowi społecznemu, zwiększając liczbę dzieci nieślubnych odtrącanych przez społeczeństwo. Większość tych nieszczęśliwych istot zawdzięcza swe powstanie przypadkowemu upiciu się matek. [...] nic tedy dziwnego, że dzieci nieślubne dostarczają znacznego kontyngensu ludzi zwyrodniałych, zbrodniarzy i prostytutek”. W. Chodecki, Alkoholizm a prostytucja, „Zdrowie” 1908, s. 305. Zob. także Z. D. Golińska, Alkoholizm jako objaw choroby społecznej, Kraków 1905, s. 28; J. Wiśniewski, Kilka słów o prostytucyi, „Zdrowie” 1906, s. 537-538.

${ }^{59}$ A. Okolski, Rzecz o dzieciobójstwie, „Czasopismo Poświęcone Prawu i Umiejętnościom Politycznym” 1864, s. 521-575.

${ }^{60}$,Znakomity wychowawca i pedagog - Pestalozzi, po zbadaniu całego szeregu aktów sądowych, nabrał przekonania, że nadzwyczaj często dzieciobójstwo bywa popełniane przez matkę bezpośrednio po urodzeniu nieprawego dziecka, wprost mechanicznie, w jakimś wrodzonym chorobliwym lęku i wstydzie, graniczącym z pewnym defektem zmysłowym”. M.S., Z badań nad niedola kobieca, „Prawda” 1910, nr 42, s. 4. 
łecznej. Dotyczyło to jednak wąskiej elity społeczników. W kręgach burżuazji i ziemiaństwa modne stało się finansowanie przedsięwzięć związanych z opieką nad ubogimi nieślubnymi matkami i ich dziećmi, mających zapobiegać dzieciobójstwu i porzuceniom. Zdecydowana większość społeczeństwa nadal traktowała ten problem z niechęcią. Istotnym sposobem wspierania ubogich matek i ich dzieci było zakładanie w miastach Królestwa, na wzór francuskich organizacji, sieci poradni wydających mleko dla niemowląt z najuboższych środowisk, tzw. Kropli Mleka; pierwsza z nich powstała w Łodzi w 1904 r. Była to realna forma pomocy, z której szybko zaczęły korzystać rzesze kobiet. Trudno ocenić, w jakim stopniu funkcjonowanie tych poradni oraz zakładanie przytułków dla rodzących wpłynęło na zmniejszenie skali przestępstw wobec niemowląt, niemniej na początku XX w. odnotowywano mniej przypadków dzieciobójstwa i drastycznych przejawów działalności ,fabrykantek aniołków”. Ale ubóstwo, analfabetyzm matek, brak stałego wsparcia ze strony administracji państwowej były głównymi przeszkodami, utrudniającymi zlikwidowanie patologii, których ofiarami były najmłodsze dzieci. Z problemami tymi borykano się również w okresie II Rzeczypospolitej. 
